\title{
Effect of Heat Treatment on Chemical Segregation in CMSX-4 Nickel-Base Superalloy
}

\author{
A. Szczotok and B. Chmiela
}

(Submitted September 19, 2013; in revised form December 9, 2013; published online December 25, 2013)

\begin{abstract}
Superalloys display a strong tendency toward chemical segregation during solidification. Therefore, it is of great importance to develop appropriate techniques for the melting and casting of superalloys. Elements partitioning between the $\gamma$ and $\gamma^{\prime}$ phases in single crystal superalloys have been investigated by several authors using electron probe microanalysis (Hemmersmeier and Feller-Kniepmeier Mater Sci Eng A 248:87-97, 1998; Kearsey et al. Intermetallics 12:903-910, 2004; Kearsey et al. Superalloys 2004, pp 801810, 2004; D'Souza et al. Mater Sci Eng A 490:258-265, 2008). We examined the effect of the particular stages of standard heat treatment (solution treatment and ageing) applied to CMSX-4 single crystal superalloy on chemical segregation that occurs between dendrites and interdendritic areas. Dendritic structures were observed using a scanning electron microscope. Analyses of the chemical composition were performed using energy dispersive $x$-ray spectroscopy. The obtained qualitative and quantitative results for the concentrations of elements enabled us to confirm the dendritic segregation in as-cast CMSX-4 superalloy. The concentrations of some refractory elements (tungsten, rhenium) were much greater in dendrites than in interdendritic areas. However, these differences in chemical composition gradually decreased during heat treatment. The results obtained in this study warrant further examination of the diffusion processes of elements during heat treatment of the investigated superalloy, and of the kinetics of diffusion.
\end{abstract}

Keywords superalloys, single crystal, heat treatment, homogenization, segregation

\section{Introduction}

CMSX-4 nickel-based superalloy has been successfully developed for turbine blade applications. The greatest advances in increasing the allowable working temperature of turbine blades over the last 30 years have been due to the development of the single crystal superalloy casting process, and the cooling and coatings of the blades. A dendritic structure is a characteristic element of a directional solidified superalloy microstructure. Each dendrite consists of primary arms (PDAs), secondary arms (SDAs), tertiary arms (TDAs), and so-called interdendritic regions (IR) containing micropores and eutectic areas. Figure 1 shows the dendrite pattern and interdendritic regions in the as-cast condition of the investigated CMSX-4 superalloy.

During solidification of single crystal (SX) superalloys, some elements ( $\mathrm{Co}, \mathrm{Re}, \mathrm{W}, \mathrm{Cr}, \mathrm{Mo}$ ) partition to the dendrite core regions, while other elements ( $\mathrm{Ti}, \mathrm{Al}, \mathrm{Ta})$ tend to accumulate in the interdendritic liquid and then solidify as

This article is an invited paper selected from presentations at the 9th International Conference on Diffusion in Solids and Liquids: DSL2013, held June 24-28, 2013, in Madrid, Spain, and has been expanded from the original presentation.

A. Szczotok and B. Chmiela, Silesian University of Technology, Krasińskiego 8, 40-019 Katowice, Poland. Contact e-mail: bartosz.chmiela@polsl.pl. the interdendritic and eutectic regions (Ref 3). Studies performed by Ma and Grafe on as-cast CMSX-4 (Ref 5) indicated that the elements $\mathrm{Ta}, \mathrm{Al}$, and $\mathrm{Ti}$ enrich the interdendritic region and $\mathrm{Co}, \mathrm{W}$, and Re segregate inversely to the dendrite core. The element $\mathrm{Cr}$ shows a homogeneous distribution across the cell. In the work (Ref 6) it has been found that in CMSX-4 in the ascast condition $\mathrm{Co}, \mathrm{Cr}, \mathrm{Re}$, and $\mathrm{W}$ partition to the dendrite cores and $\mathrm{Al}, \mathrm{Ni}, \mathrm{Ti}$, Ta segregate to the interdendritic regions. It was notable that the heavy elements $\mathrm{Re}, \mathrm{Ta}$, and $\mathrm{W}$ segregated particularly strong. During solution heat treatment at $1315^{\circ} \mathrm{C}$ (which is approximately equal to the equllibrium solvus temperature of the alloy), the dendritic and interdendritic regions homogenise at different rates. Enrichment of some solutes, e.g., $\mathrm{Ta}, \mathrm{Co}$, and $\mathrm{Cr}$ occurs in the eutectic region. During heat treatment, the elements partition to the opposite site (as compared to the solidification process used to obtain homogeneity, or at least an improvement in chemical inhomogeneity)-Fig. 2. According to the results presented in (Ref 7) for SX CMSX-10 superalloy during high temperature diffusion $\mathrm{Al}, \mathrm{Ni}$, and Ta partition to the dendrite cores, and $\mathrm{W}, \mathrm{Re}, \mathrm{Cr}$, and Co segregate toward the interdendritic regions.

The microstructure formation during directional solidification was simulated using a unit-cell approach in Ref 8 . The concept was based on a model introduced by Ma (Ref 9).

The non-equilibrium solidification conditions of superalloys result in the segregation of the alloying elements within the dendritic cell. Segregation deteriorates material properties because the local composition deviates from the optimized total composition. Segregation is described by the phase diagram and follows a general rule: if an alloying element increases the solidus temperature, it enriches the dendrite arms; otherwise, it concentrates in the interdendritic regions (Fig. 3) (Ref 10). 


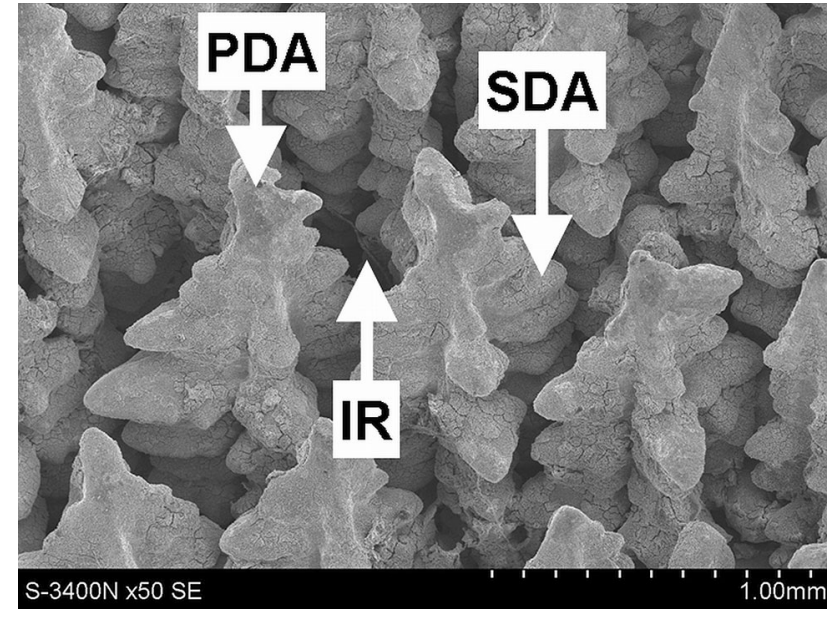

Fig. 1 Dendrites of a single crystal bar made of CMSX-4 superalloy

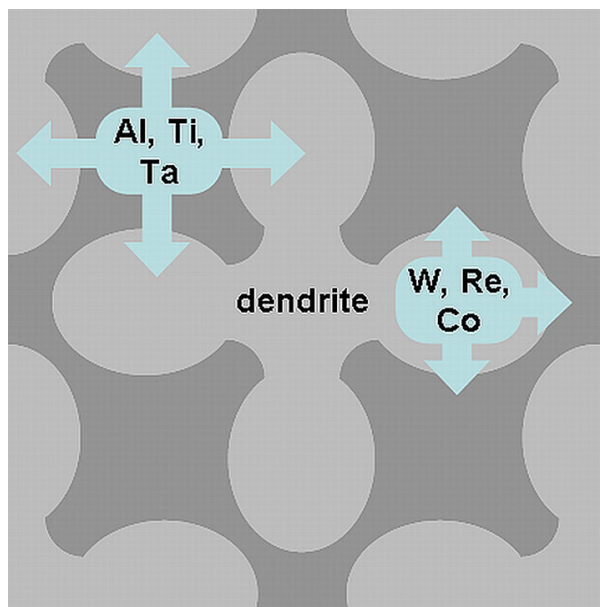

Fig. 2 Diffusion mechanism in single crystal nickel-base superalloy during heat treatment. Some elements partition to the dendrite core, and some to the interdendritic regions
The segregation coefficient $K$ is defined as the ratio of the concentration of the elements in the dendrite core to those in the interdendritic region: $K=C_{\mathrm{d}} / C_{\mathrm{i}}$, where $C_{\mathrm{d}}$ is the concentration of elements in dendrite core, and $C_{\mathrm{i}}$ is the concentration of

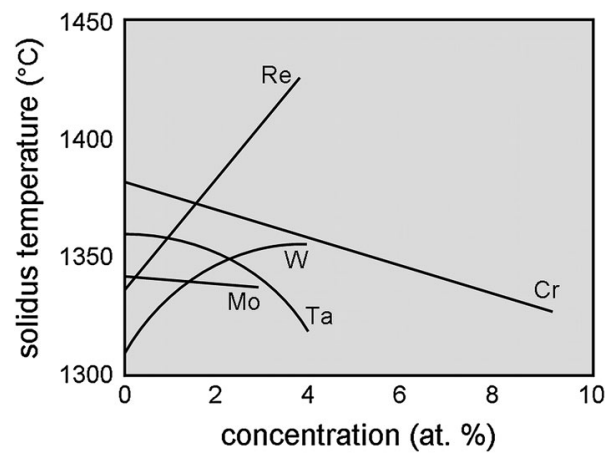

Fig. 3 Influence of different additions on the solidus temperature of nickel-base superalloys (Ref 10)

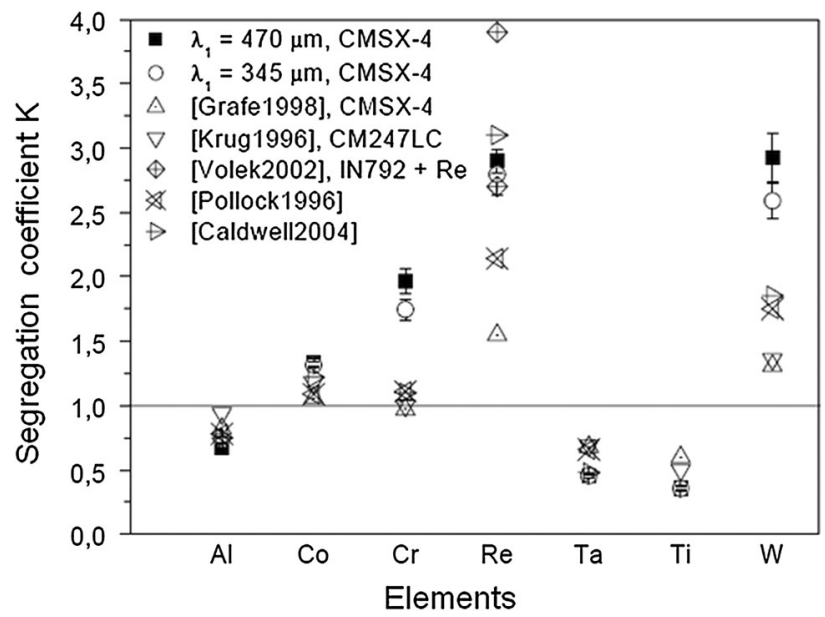

Fig. 4 Segregation coefficient $K$ determined for three superalloys ( $\lambda_{1}$ primary dendrite arm spacing) (Ref 11$)$

Table 1 Heat treatment schemes applied in the study

\begin{tabular}{|c|c|}
\hline $\begin{array}{l}\text { No. of } \\
\text { specimen }\end{array}$ & Conditions of heat treatment \\
\hline 0 & As-cast \\
\hline 1 & $1277^{\circ} \mathrm{C} / 2 \mathrm{~h}$ \\
\hline 2 & $1277^{\circ} \mathrm{C} / 2 \mathrm{~h}+1288^{\circ} \mathrm{C} / 2 \mathrm{~h}$ \\
\hline 3 & $1277{ }^{\circ} \mathrm{C} / 2 \mathrm{~h}+1288^{\circ} \mathrm{C} / 2 \mathrm{~h}+1296{ }^{\circ} \mathrm{C} / 3 \mathrm{~h}$ \\
\hline 4 & $1277{ }^{\circ} \mathrm{C} / 2 \mathrm{~h}+1288{ }^{\circ} \mathrm{C} / 2 \mathrm{~h}+1296{ }^{\circ} \mathrm{C} / 3 \mathrm{~h}+1304{ }^{\circ} \mathrm{C} / 3 \mathrm{~h}$ \\
\hline 5 & $1277{ }^{\circ} \mathrm{C} / 2 \mathrm{~h}+1288{ }^{\circ} \mathrm{C} / 2 \mathrm{~h}+1296{ }^{\circ} \mathrm{C} / 3 \mathrm{~h}+1304{ }^{\circ} \mathrm{C} / 3 \mathrm{~h}+1313{ }^{\circ} \mathrm{C} / 2 \mathrm{~h}$ \\
\hline 6 & $1277{ }^{\circ} \mathrm{C} / 2 \mathrm{~h}+1288{ }^{\circ} \mathrm{C} / 2 \mathrm{~h}+1296{ }^{\circ} \mathrm{C} / 3 \mathrm{~h}+1304{ }^{\circ} \mathrm{C} / 3 \mathrm{~h}+1313{ }^{\circ} \mathrm{C} / 2 \mathrm{~h}+1316{ }^{\circ} \mathrm{C} / 2 \mathrm{~h}$ \\
\hline 7 & $1277{ }^{\circ} \mathrm{C} / 2 \mathrm{~h}+1288{ }^{\circ} \mathrm{C} / 2 \mathrm{~h}+1296{ }^{\circ} \mathrm{C} / 3 \mathrm{~h}+1304{ }^{\circ} \mathrm{C} / 3 \mathrm{~h}+1313{ }^{\circ} \mathrm{C} / 2 \mathrm{~h}+1316{ }^{\circ} \mathrm{C} / 2 \mathrm{~h}+1318{ }^{\circ} \mathrm{C} / 2 \mathrm{~h}$ \\
\hline 8 & $1277{ }^{\circ} \mathrm{C} / 2 \mathrm{~h}+1288{ }^{\circ} \mathrm{C} / 2 \mathrm{~h}+1296{ }^{\circ} \mathrm{C} / 3 \mathrm{~h}+1304{ }^{\circ} \mathrm{C} / 3 \mathrm{~h}+1313{ }^{\circ} \mathrm{C} / 2 \mathrm{~h}+1316{ }^{\circ} \mathrm{C} / 2 \mathrm{~h}+1318{ }^{\circ} \mathrm{C} / 2 \mathrm{~h}+1321{ }^{\circ} \mathrm{C} / 2 \mathrm{~h}$ \\
\hline 9 & $1277^{\circ} \mathrm{C} / 2 \mathrm{~h}+1288^{\circ} \mathrm{C} / 2 \mathrm{~h}+1296{ }^{\circ} \mathrm{C} / 3 \mathrm{~h}+1304{ }^{\circ} \mathrm{C} / 3 \mathrm{~h}+1313{ }^{\circ} \mathrm{C} / 2 \mathrm{~h}+1316^{\circ} \mathrm{C} / 2 \mathrm{~h}+1318{ }^{\circ} \mathrm{C} / 2 \mathrm{~h}+1321{ }^{\circ} \mathrm{C} / 2 \mathrm{~h}+1140{ }^{\circ} \mathrm{C} / 6 \mathrm{~h}$ \\
\hline 10 & $\begin{array}{l}1277{ }^{\circ} \mathrm{C} / 2 \mathrm{~h}+1288^{\circ} \mathrm{C} / 2 \mathrm{~h}+1296{ }^{\circ} \mathrm{C} / 3 \mathrm{~h}+1304{ }^{\circ} \mathrm{C} / 3 \mathrm{~h}+1313{ }^{\circ} \mathrm{C} / 2 \mathrm{~h}+1316{ }^{\circ} \mathrm{C} / 2 \mathrm{~h}+1318{ }^{\circ} \mathrm{C} / 2 \mathrm{~h}+1321{ }^{\circ} \mathrm{C} / 2 \mathrm{~h}+1140{ }^{\circ} \mathrm{C} / 6 \mathrm{~h} \\
+870{ }^{\circ} \mathrm{C} / 20 \mathrm{~h}\end{array}$ \\
\hline
\end{tabular}




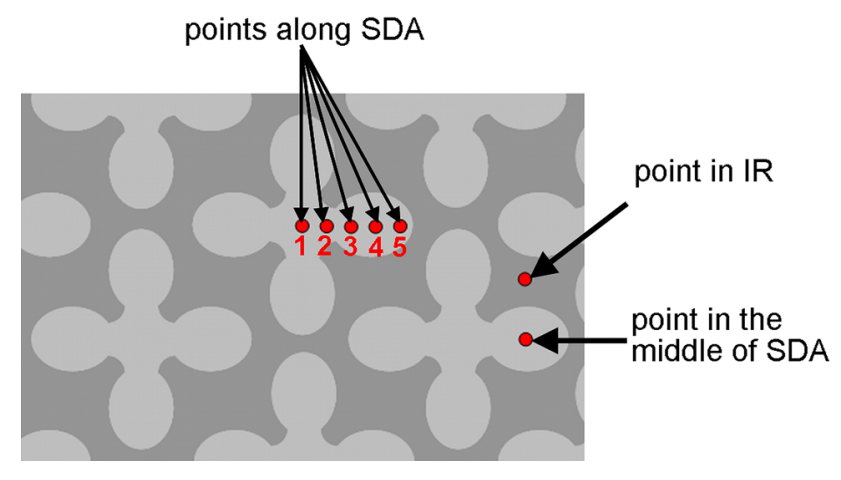

Fig. 5 Schematic of dendritic pattern in the microstructure of a single crystal superalloy with marked areas showing locations of chemical composition measurements elements in the interdendritic regions. The selected results of the determination of segregation coefficient $K$ for seven elements occurring in the three superalloys are presented in Fig. 4.

Concentration gradients exist between the central and peripheral dendrite parts because of element segregation during dendrite growth. This chemical inhomogeneity causes a change in the structure's parameters.

Diffusion-related phenomena have become an increasingly important consideration for both the processing and usage of superalloys (Ref 12). In the solidification process of a single crystal superalloy, the dendrites grow at a rate that is greatly controlled by the diffusion of the solute (Ref 13). In the heattreatment process, atomic diffusion becomes accelerated in order to generate the microstructure, which is stable during operations over a prolonged period. During the service, the creep strain rate is proportional to the diffusion coefficient (Ref 14).
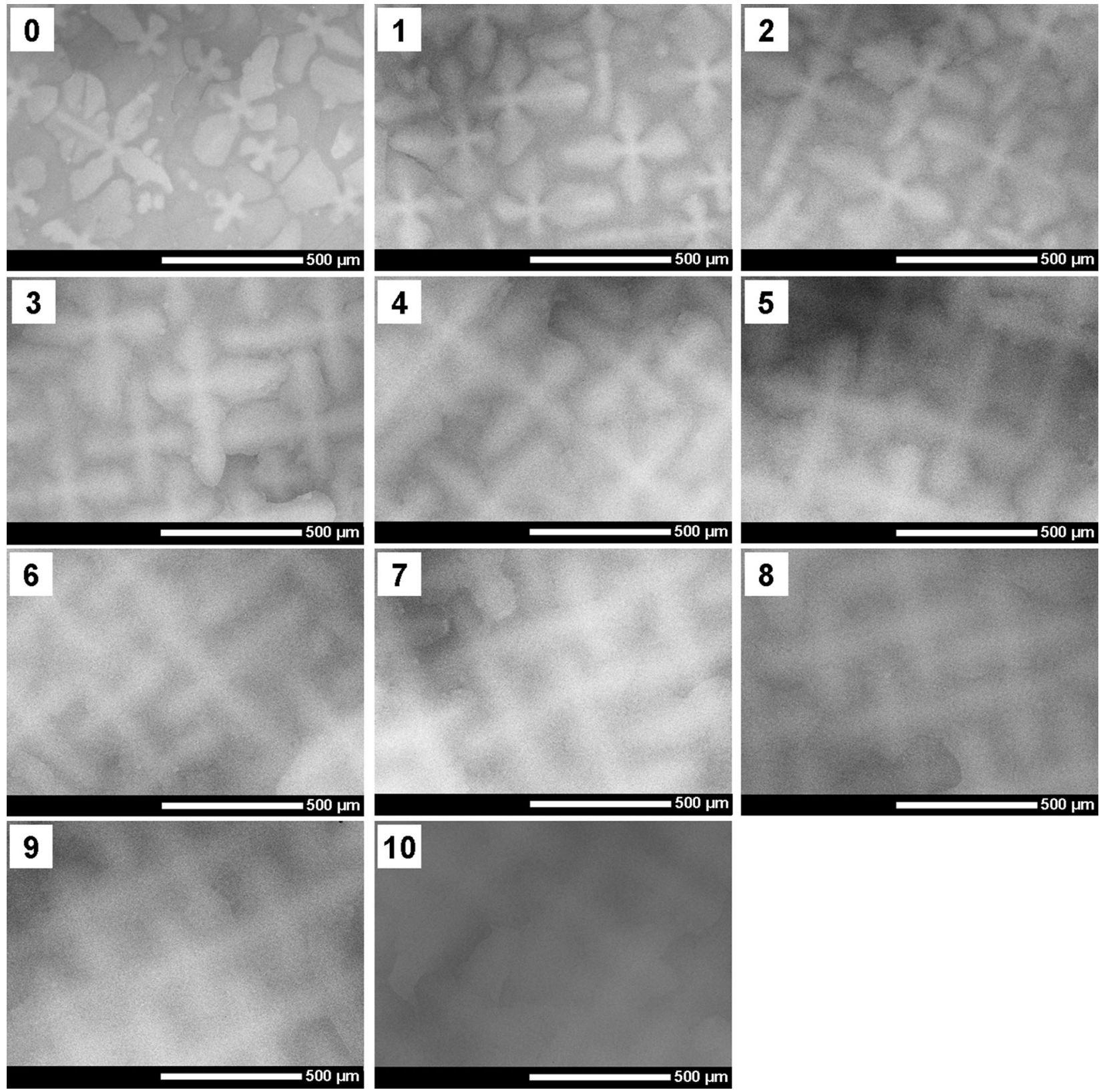

Fig. 6 Dendritic structure of the investigated CMSX-4 superalloy as-cast (sample 0), and after each stage of applied heat treatment (samples from 1 to 8 represent solution heat treatment; samples 9 and 10 represent aging) 
The composition of CMSX-4 superalloy is complex and is characterized by a rather high refractory metals level $(\mathrm{Mo}+\mathrm{Ta}+\mathrm{W}+\mathrm{Re}$ ) of greater than $10 \mathrm{wt} . \%$. These elements provide solid solution strengthening, are characterized by slow diffusion rates, and decrease the diffusion rate of other alloying elements during solution heat treatment (Ref 15). In superalloys with a high volume fraction $\left(\gamma+\gamma^{\prime}\right)$ of eutectic after casting, the complete dissolution of $\gamma^{\prime}$ during heat treatment is very important. That is why increased solution heat treatment temperatures and times are required to facilitate eutectic dissolve, and to achieve a chemical homogeneity (i.e., the elimination or at a least reduction of the segregation). To dissolve primary $\gamma^{\prime}$ and to reduce the degree of microsegregation directional solidificated single crystal superalloy is heated up to temperatures around $1200-1300{ }^{\circ} \mathrm{C}$ for up to $40 \mathrm{~h}(\operatorname{Ref} 8)$.

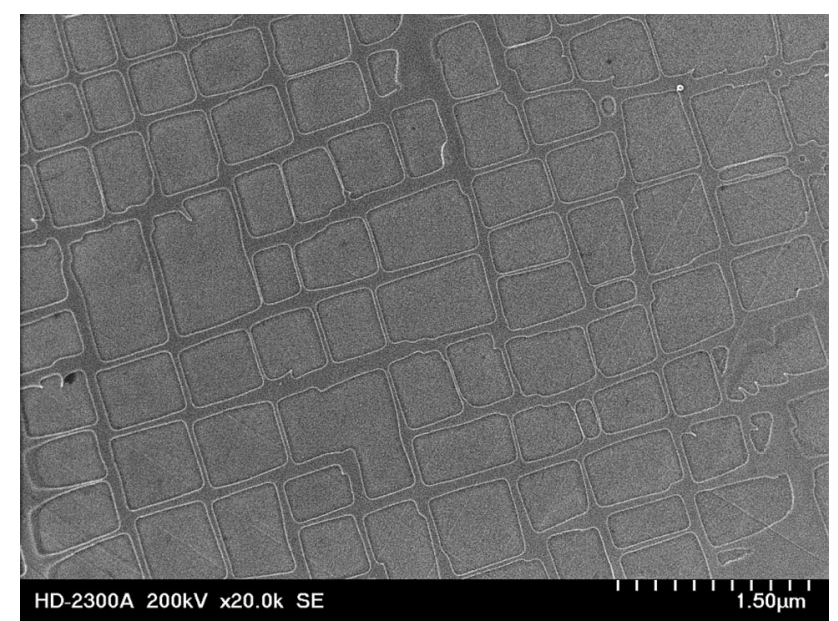

Fig. 7 Microstructure of CMSX-4 superalloy (sample No. 10) after full heat treatment
In CMSX-4 superalloy, the Re content is 3 wt.\%. Rhenium is among the most dense and least compressible of the transition metals due to its configuration of electrons. Addition of $\mathrm{Re}$ in nickel-base superalloys causes directional and incompressible $\mathrm{Ni}-\mathrm{Re}$ bonds to be formed, which hinder vacancy migration. This effect dominates over any differences in the vacancy-solute binding energy and any influence of the atomic radius on the solute, and explains why $\mathrm{Re}$ has a profound effect on the properties of the superalloy (Ref 14, 16).

The microstructure of CMSX-4 superalloy is well known, and consists of two-phase $\left(\gamma+\gamma^{\prime}\right)$. In the as-cast condition, the superalloy is characterized by $\gamma$ matrix, $\gamma^{\prime}$ phase precipitates, and $\left(\gamma+\gamma^{\prime}\right)$ eutectic regions. The microstructure of the as-cast CMSX-4 superalloy can be optimized to be a full solution and have the lowest possible level of residual microsegregation. The microstructure cannot contain: $\left(\gamma+\gamma^{\prime}\right)$ eutectic phase, regions of incipient melting, carbides, and microporosity.

Both the $\gamma^{\prime}$ precipitate size and the distribution can significantly affect the mechanical properties of a single crystal Ni-base superalloy at room and elevated temperature (Ref 17). Microsegregation-induced inhomogeneity of the coarsening of cuboidal $\gamma^{\prime}\left(\mathrm{Ni}_{3}(\mathrm{Al}, \mathrm{Ti})\right)$ precipitates was studied in a single crystal nickel-based superalloy CMSX-4 at temperatures ranging from 850 to $1000{ }^{\circ} \mathrm{C}$ and for an ageing time up to $5000 \mathrm{~h}$ in Ref 18. Experimental results showed a significant statistical difference in the size of the $\gamma^{\prime}$ precipitates between the dendrites and interdendritic region. The mean size distribution of the $\gamma^{\prime}$-phase precipitates depend on the chemical homogeneity of the material since the local composition is known to strongly determine the precipitation kinetics (Ref 19, 20).

We studied the chemical distribution of elements in dendrites and among them, and microstructural changes in the CMSX-4 superalloy resulting from the stages of standard heat treatment. The main objective of this study was to investigate the effect of $\mathrm{Re}, \mathrm{W}, \mathrm{Co}, \mathrm{Mo}, \mathrm{Cr}$, Ta, and $\mathrm{Ti}$ on the segregation behavior of CMSX-4 superalloy.

Table 2 Mean values of element concentration in dendrites (wt.\%)

\begin{tabular}{|c|c|c|c|c|c|c|c|c|c|c|}
\hline & & Mo & $\mathbf{T i}$ & $\mathbf{R e}$ & Al & Ta & $\mathrm{Cr}$ & $\mathbf{W}$ & Co & $\mathbf{N i}$ \\
\hline \multirow[t]{2}{*}{0} & Mean value & 0.6 & 0.6 & 5.5 & 4.4 & 5.0 & 6.3 & 8.3 & 10.6 & 58.7 \\
\hline & $\mathrm{SD}$ & 0.09 & 0.02 & 0.13 & 0.19 & 0.45 & 0.38 & 0.35 & 0.57 & 0.54 \\
\hline \multirow[t]{2}{*}{1} & Mean value & 0.6 & 0.8 & 3.9 & 4.7 & 6.0 & 6.6 & 7.7 & 9.8 & 59.8 \\
\hline & $\mathrm{SD}$ & 0.08 & 0.04 & 0.17 & 0.10 & 0.93 & 0.12 & 0.17 & 0.16 & 0.75 \\
\hline \multirow[t]{2}{*}{2} & Mean value & 0.6 & 0.9 & 4.1 & 4.4 & 6.3 & 6.6 & 7.7 & 9.6 & 59.9 \\
\hline & SD & 0.09 & 0.05 & 0.16 & 0.17 & 0.85 & 0.09 & 0.32 & 0.36 & 0.53 \\
\hline \multirow[t]{2}{*}{3} & Mean value & 0.6 & 0.9 & 3.7 & 4.8 & 6.9 & 6.5 & 7.1 & 9.5 & 59.9 \\
\hline & SD & 0.17 & 0.08 & 0.12 & 0.07 & 0.86 & 0.12 & 0.37 & 0.13 & 0.28 \\
\hline \multirow[t]{2}{*}{4} & Mean value & 0.6 & 0.9 & 3.5 & 4.9 & 6.5 & 6.5 & 7.1 & 9.5 & 60.4 \\
\hline & $\mathrm{SD}$ & 0.05 & 0.03 & 0.26 & 0.08 & 1.02 & 0.11 & 0.19 & 0.17 & 0.83 \\
\hline \multirow[t]{2}{*}{5} & Mean value & 0.6 & 0.9 & 3.5 & 4.8 & 6.7 & 6.4 & 7.1 & 9.5 & 60.4 \\
\hline & $\mathrm{SD}$ & 0.07 & 0.09 & 0.12 & 0.08 & 0.72 & 0.15 & 0.24 & 0.31 & 0.35 \\
\hline \multirow[t]{2}{*}{6} & Mean value & 0.7 & 0.9 & 3.5 & 4.8 & 7.2 & 6.3 & 6.9 & 9.4 & 60.3 \\
\hline & $\mathrm{SD}$ & 0.05 & 0.09 & 0.23 & 0.07 & 0.45 & 0.16 & 0.21 & 0.09 & 0.35 \\
\hline \multirow[t]{2}{*}{7} & Mean value & 0.6 & 1.0 & 3.4 & 4.9 & 7.0 & 6.4 & 6.7 & 9.2 & 60.9 \\
\hline & SD & 0.06 & 0.04 & 0.10 & 0.07 & 0.60 & 0.09 & 0.12 & 0.09 & 0.51 \\
\hline \multirow[t]{2}{*}{8} & Mean value & 0.6 & 0.9 & 3.2 & 4.9 & 7.9 & 5.9 & 6.6 & 8.9 & 61.1 \\
\hline & $\mathrm{SD}$ & 0.14 & 0.10 & 0.20 & 0.15 & 0.66 & 0.23 & 0.14 & 0.45 & 0.50 \\
\hline \multirow[t]{2}{*}{9} & Mean value & 0.6 & 1.0 & 3.4 & 4.7 & 7.3 & 6.4 & 6.7 & 9.2 & 60.8 \\
\hline & $\mathrm{SD}$ & 0.15 & 0.10 & 0.93 & 0.49 & 1.82 & 1.04 & 0.49 & 0.83 & 1.61 \\
\hline \multirow[t]{2}{*}{10} & Mean value & 0.6 & 0.9 & 3.3 & 4.7 & 7.5 & 6.3 & 6.7 & 9.5 & 60.5 \\
\hline & SD & 0.12 & 0.11 & 0.63 & 0.36 & 1.02 & 1.14 & 0.18 & 0.99 & 1.95 \\
\hline
\end{tabular}


Table 3 Mean values of element concentration in interdendritic regions (wt.\%)

\begin{tabular}{|c|c|c|c|c|c|c|c|c|c|c|}
\hline & & Mo & $\mathbf{T i}$ & $\mathbf{R e}$ & Al & Ta & $\mathrm{Cr}$ & $\mathbf{W}$ & Co & $\mathbf{N i}$ \\
\hline \multirow[t]{2}{*}{0} & Mean value & 0.7 & 1.2 & 2.2 & 5.4 & 8.3 & 6.1 & 5.6 & 9.2 & 61.3 \\
\hline & $\mathrm{SD}$ & 0.21 & 0.32 & 1.25 & 0.52 & 2.4 & 1.77 & 0.67 & 0.94 & 1.65 \\
\hline \multirow[t]{2}{*}{1} & Mean value & 0.5 & 1.1 & 2.1 & 5.2 & 8.4 & 5.7 & 5.4 & 8.9 & 62.7 \\
\hline & SD & 0.14 & 0.15 & 0.63 & 0.29 & 1.70 & 0.86 & 0.74 & 0.57 & 1.04 \\
\hline \multirow[t]{2}{*}{2} & Mean value & 0.5 & 1.2 & 1.8 & 5.0 & 8.4 & 5.5 & 5.1 & 8.7 & 63.7 \\
\hline & SD & 0.21 & 0.22 & 0.98 & 0.69 & 2.09 & 1.75 & 0.95 & 1.19 & 2.29 \\
\hline \multirow[t]{2}{*}{3} & Mean value & 0.5 & 1.1 & 2.7 & 5.1 & 7.3 & 6.2 & 5.9 & 9.4 & 61.6 \\
\hline & $\mathrm{SD}$ & 0.08 & 0.09 & 0.30 & 0.19 & 0.69 & 0.18 & 0.31 & 0.27 & 0.30 \\
\hline \multirow[t]{2}{*}{4} & Mean value & 0.6 & 1.0 & 2.2 & 5.4 & 8.1 & 6.1 & 5.7 & 9.2 & 61.8 \\
\hline & SD & 0.10 & 0.08 & 0.30 & 0.31 & 0.75 & 0.28 & 0.26 & 0.18 & 0.31 \\
\hline \multirow[t]{2}{*}{5} & Mean value & 0.5 & 1.0 & 1.8 & 5.6 & 9.0 & 5.3 & 5.5 & 8.5 & 62.8 \\
\hline & $\mathrm{SD}$ & 0.20 & 0.21 & 1.09 & 0.66 & 1.70 & 1.44 & 0.80 & 0.90 & 2.08 \\
\hline \multirow[t]{2}{*}{6} & Mean value & 0.5 & 1.0 & 2.5 & 5.0 & 7.9 & 6.1 & 6.2 & 9.3 & 61.5 \\
\hline & SD & 0.11 & 0.08 & 0.30 & 0.04 & 0.72 & 0.12 & 0.38 & 0.39 & 0.76 \\
\hline \multirow[t]{2}{*}{7} & Mean value & 0.6 & 0.9 & 2.5 & 5.1 & 7.4 & 6.1 & 6.1 & 9.0 & 62.3 \\
\hline & SD & 0.12 & 0.07 & 0.22 & 0.06 & 1.14 & 0.13 & 0.13 & 0.39 & 1.04 \\
\hline \multirow[t]{2}{*}{8} & Mean value & 0.6 & 1.0 & 2.5 & 5.0 & 7.6 & 6.1 & 6.2 & 9.1 & 61.9 \\
\hline & SD & 0.12 & 0.06 & 0.23 & 0.15 & 0.47 & 0.21 & 0.18 & 0.18 & 0.58 \\
\hline \multirow[t]{2}{*}{9} & Mean value & 0.6 & 1.1 & 2.1 & 5.2 & 8.3 & 5.5 & 5.8 & 8.6 & 62.9 \\
\hline & SD & 0.10 & 0.05 & 0.53 & 0.28 & 1.03 & 0.71 & 0.38 & 0.52 & 0.94 \\
\hline \multirow[t]{2}{*}{10} & Mean value & 0.6 & 0.9 & 2.5 & 4.9 & 8.5 & 5.9 & 6.2 & 9.0 & 61.4 \\
\hline & SD & 0.10 & 0.15 & 0.62 & 0.37 & 0.87 & 0.82 & 0.31 & 0.66 & 1.15 \\
\hline
\end{tabular}

Table 4 Segregation coefficient $K$ (the minimum and the maximum values of $K$ are shown in bold)

\begin{tabular}{|c|c|c|c|c|c|c|c|c|c|}
\hline & Mo & $\mathbf{T i}$ & $\mathbf{R e}$ & Al & Ta & $\mathrm{Cr}$ & $\mathbf{W}$ & Co & $\mathbf{N i}$ \\
\hline 0 & 0.84 & 0.51 & 2.51 & 0.82 & 0.60 & 1.03 & 1.49 & 1.15 & 0.96 \\
\hline 1 & 1.11 & 0.74 & 1.90 & 0.89 & 0.72 & 1.16 & 1.44 & 1.10 & 0.95 \\
\hline 2 & 1.06 & 0.77 & 2.21 & 0.87 & 0.74 & 1.20 & 1.50 & 1.11 & 0.94 \\
\hline 3 & 1.15 & 0.88 & 1.35 & 0.94 & 0.94 & 1.04 & 1.21 & 1.01 & 0.97 \\
\hline 4 & 1.07 & 0.95 & 1.59 & 0.92 & 0.80 & 1.06 & 1.25 & 1.03 & 0.98 \\
\hline 5 & 1.21 & 0.89 & 1.92 & 0.86 & 0.75 & 1.21 & 1.28 & 1.12 & 0.96 \\
\hline 6 & 1.25 & 0.94 & 1.39 & 0.96 & 0.91 & 1.03 & 1.12 & 1.01 & 0.98 \\
\hline 7 & 0.93 & 1.05 & 1.35 & 0.97 & 0.95 & 1.05 & 1.10 & 1.02 & 0.98 \\
\hline 8 & 0.95 & 0.88 & 1.32 & 0.98 & 1.04 & 0.97 & 1.07 & 0.98 & 0.99 \\
\hline 9 & 0.95 & 0.86 & 1.65 & 0.90 & 0.89 & 1.15 & 1.16 & 1.07 & 0.97 \\
\hline 10 & 1.02 & 0.99 & 1.29 & 0.97 & 0.88 & 1.06 & 1.08 & 1.06 & 0.99 \\
\hline
\end{tabular}

\section{Experimental}

CMSX-4 is a vacuum-melted cast superalloy. In this study, the CMSX-4 was available in the form of a single crystal bar of $10 \mathrm{~mm}$ diameter, obtained using the Bridgman method. The chemical composition of the superalloy (in wt.\%) is $9.0 \mathrm{Co}, 6.5$ $\mathrm{Cr}, 6.0 \mathrm{~W}, 5.6 \mathrm{Al}, 1.0 \mathrm{Ti}, 6.5 \mathrm{Ta}, 0.6 \mathrm{Mo}, 3.0 \mathrm{Re}, 0.1 \mathrm{Hf}$, and a $\mathrm{Ni}$ balance. Slices of the bar were cut off and heat treated according the schemes shown in Table 1. The sample No. 0 was as-cast without heat treatment. Samples from No. 1 to No. 8 were heat treated with increasing temperature and hold time at the each temperature for 2-3 hours to obtain finally (sample No. 8 ) the homogenized state. According to Table 1, the first sample was heat treated at $1277{ }^{\circ} \mathrm{C} / 2 \mathrm{~h}$, took out from the furnace and threw into water. The second sample was heat treated longer than first sample, because after holding at $1277^{\circ} \mathrm{C} / 2 \mathrm{~h}$ the temperature was increased up to $1288^{\circ} \mathrm{C}$ and the sample was hold at the temperature for $2 \mathrm{~h}$. Then it was took out from the furnace and threw into water. The scheme of heat treatment for the further samples was similar-increase of the temperature and additional hold time at the higher temperature. Sample No. 9 and No. 10 were additionally subjected to ageing at $1140{ }^{\circ} \mathrm{C} / 6 \mathrm{~h}$ and $1140{ }^{\circ} \mathrm{C} / 6 \mathrm{~h}+870{ }^{\circ} \mathrm{C} /$ $20 \mathrm{~h}$, respectively. Each sample after finished heat treatment scheme was taken out from the furnace and thrown into water.

After every stage of heat treatment, the samples were metallographically prepared and polished with 240 to 1200 grit papers. A Hitachi S-3400 N SEM was used to examine the microstructure. The back-scattered electron (BSE) technique was applied to obtain better contrast between the dendrite arms and interdendritic areas. Along the line from the dendrite core to the dendrite edge, a 5-point chemical composition analysis was carried out using EDS (Fig. 5). These measurements were performed on three SDAs for each sample. Each point revealed the local atomic composition. In addition, the chemical composition was investigated at the central point of the SDA and at the point of the interdendritic region near the SDA (along the line perpendicular to the axis of SDA, see Fig. 5). EDS 


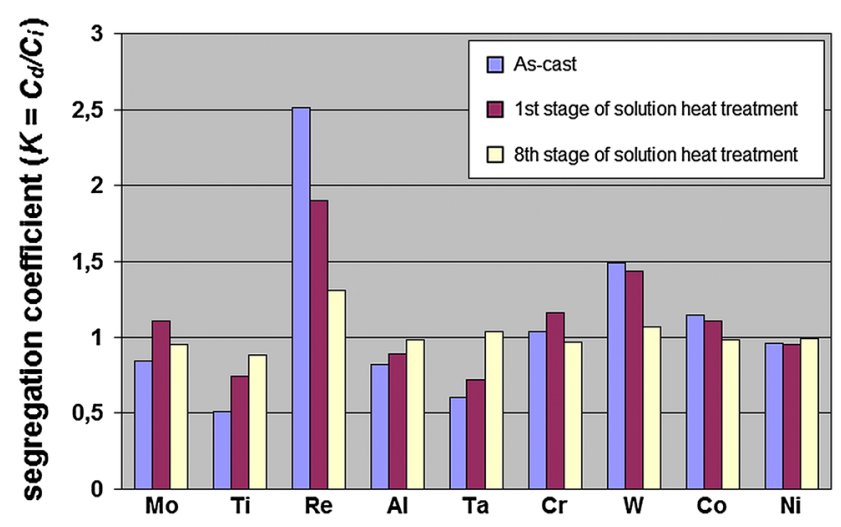

Fig. 8 Segregation coefficient $K$ for all studied elements for the case of as-cast alloy, and samples after the first and eighth stages of heat treatment of CMSX-4 superalloy
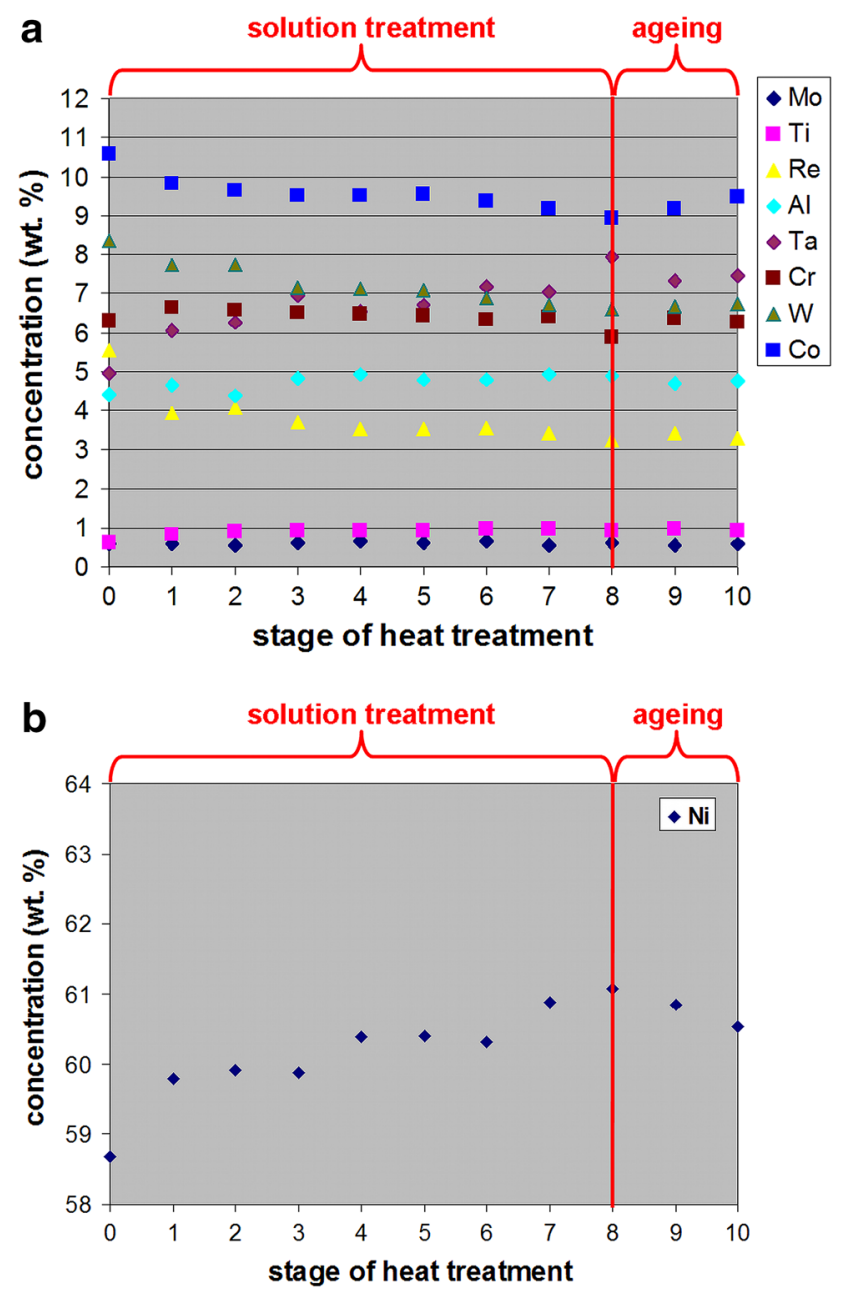

Fig. 9 Concentration of elements in dendrites in correlation with stage of the heat treatment

analysis was carried out for all samples at the five points inside the SDA and the five points in the IR. EDS analyses were performed in standardless mode. The acceleration voltage was equal to $15 \mathrm{kV}$ and working distance was $10 \mathrm{~mm}$ (optimal for the given take-off angle in the SEM).
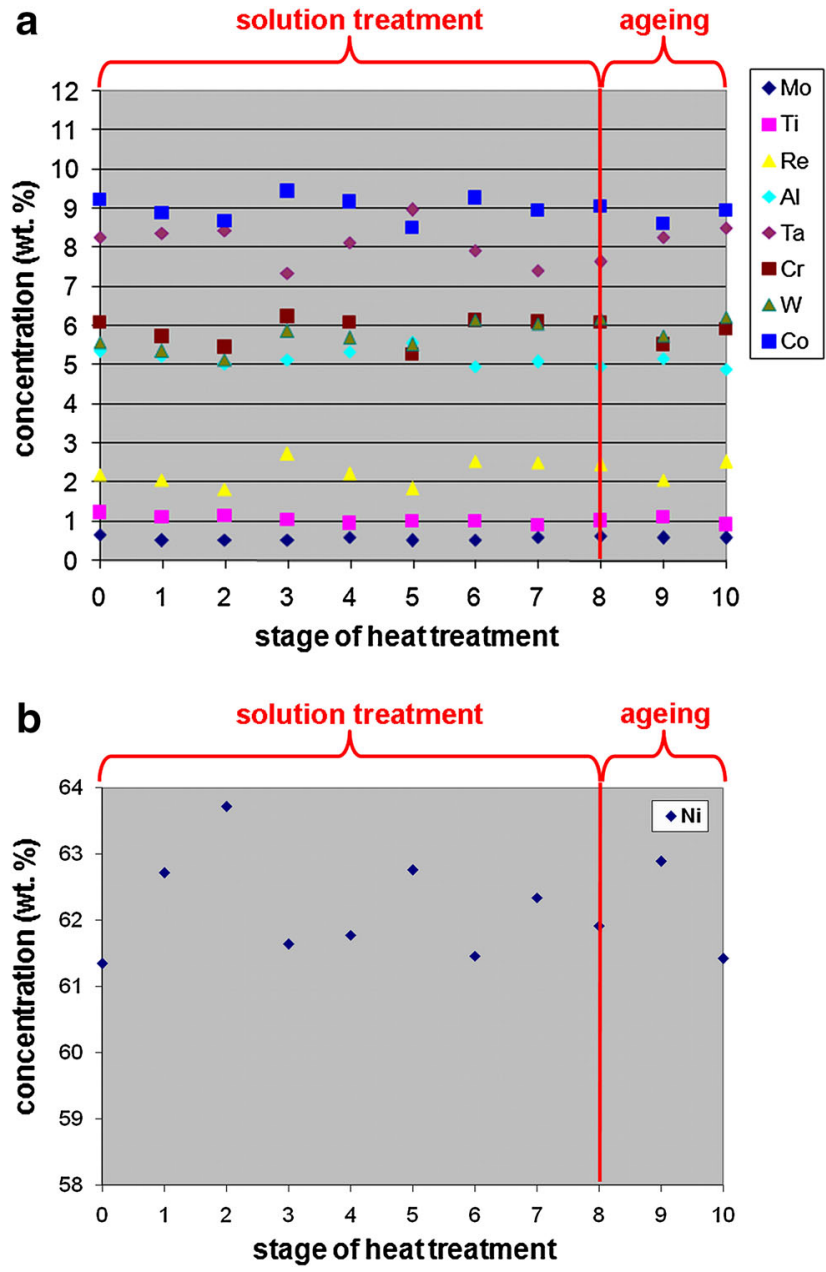

Fig. 10 Concentration of elements in interdendritic regions in correlation with the stage of heat treatment

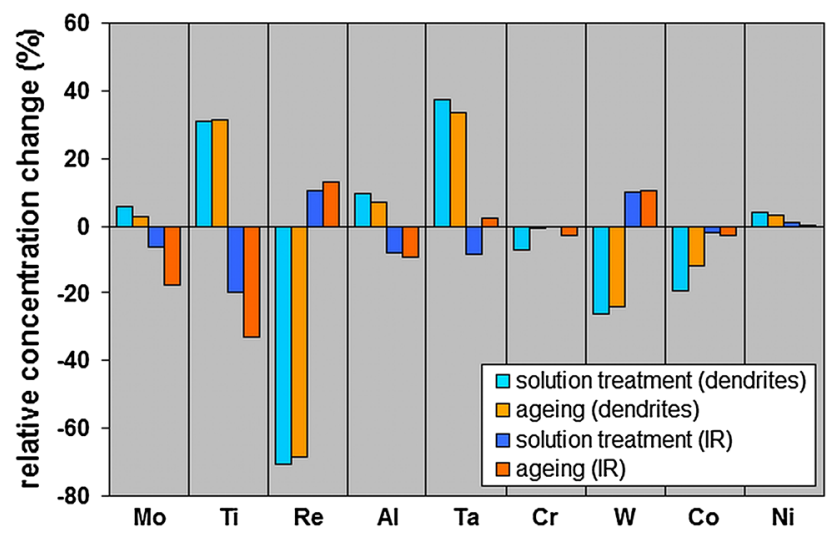

Fig. 11 Relative changes of chemical composition in the dendrites and IR after full heat treatment

\section{Results and Discussion}

The as-cast microstructure of the investigated superalloy is shown in Fig. 6. As expected, the superalloy exhibited high segregation that was confirmed by a dendritic structure. 

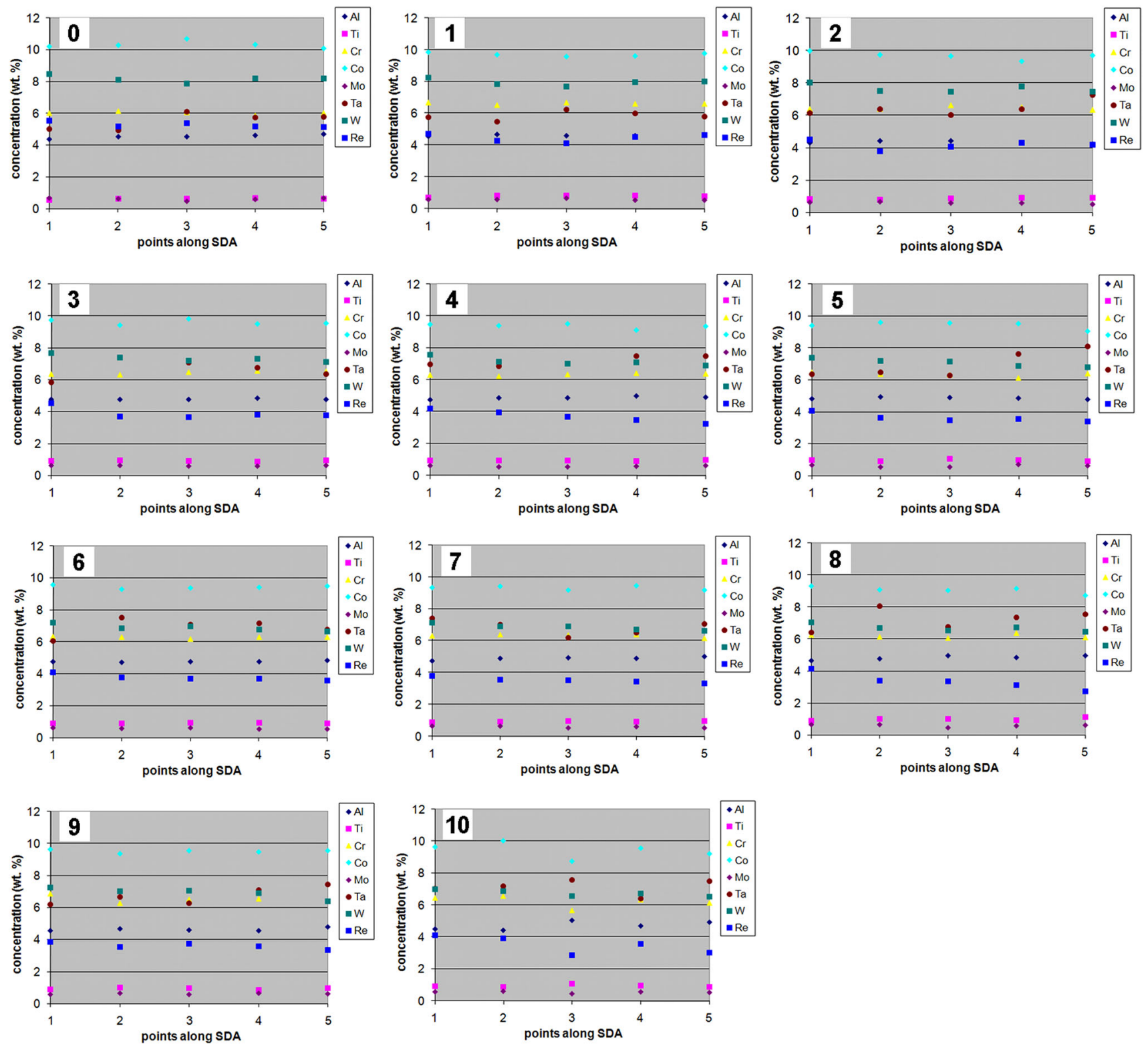

Fig. 12 Concentration of elements along SDA in as-cast sample, and after each stage of applied heat treatment (samples 0-10)

The dendritic structure was increasingly less visible after each stage of heat treatment. Two-step ageing (at $1140{ }^{\circ} \mathrm{C} / 6 \mathrm{~h}$ and $870^{\circ} \mathrm{C} / 20 \mathrm{~h}$ ) was applied for the investigated superalloy. The final microstructure exhibits well aligned rows of $\gamma^{\prime}$ precipitates with cuboidal morphology with an average size of about $0.5 \mu \mathrm{m}$ (Fig. 7). No secondary $\gamma^{\prime}$ or TCP phases precipitates were found on the No. 10 sample.

The mean values of element concentration (wt.\%), estimated during the investigations of the CMSX-4 superalloy, in the dendrites for all samples (from 0 to 10) are shown in Table 2, and as interdendritic regions in Table 3.

Table 4 shows the values of the segregation coefficient $K$ in the investigated superalloy in as-cast state and after ten steps of the heat treatment.

From these results, it was found that the value of $K$ is the highest for elements such as Re and W (even above 2 in the case of Re), and the degree of their segregation is the strongest. The $K$ values for $\mathrm{Cr}$ and $\mathrm{Co}$ are above 1 (except for the sample No. 8).
These results indicate that some disturbances occurred in the segregation process during the last stage of solution treatment. However, the elements $\mathrm{W}, \mathrm{Re}, \mathrm{Cr}$, and Co tended to segregate toward the interdendritic regions during heat treatment (see Fig. 2). The elements Ti, Al, Ta, and Ni are characterized by $K$ value of less than 1 , and they segregated toward the dendrite core regions. In the case of titanium and tantalum, the values of $K$ are slightly greater than 1 for the 7 th and 8 th stage of solution treatment, respectively. Molybdenum is characterized by an ambiguous tendency toward segregation because some fluctuations of the $K$ values were observed. The minimal and the maximal values of $K$ are 0.51 and 2.51 in the as-cast state for $\mathrm{Ti}$ and $\mathrm{Re}$, respectively. For the case of as-cast alloy and samples after selected stages of heat treatment, the segregation coefficients for all of the studied elements are shown in Fig. 7. After the 1st stage of solution treatment, considerable changes in the concentration of the elements are visible, especially for Re, W, and Co. The greatest changes in chemical composition appeared 
between the as-cast state (sample No. 0) and the 8th stage of heat treatment (after full solution treatment-see Fig. 8).

Graphical illustrations of the correlation between the stage of heat treatment and element distribution in dendrites on the basis of data included in Table 2 are presented in Fig. 9.

Similarly, graphical illustrations of the correlation between the stage of heat treatment and element distribution in interdendritic regions on the basis of data included in Table 3 are presented in Fig 10. Fluctuations of the concentration during heat treatment are clearly visible.

The concentrations of $\mathrm{Re}, \mathrm{W}$, and Co are considerably higher in dendrite cores than in interdendritic regions. In the case of $\mathrm{Cr}$, the $K$ value is close to 1 . However, the concentrations of $\mathrm{Al}, \mathrm{Ta}$, and $\mathrm{Ti}$ are higher in the IR than in the dendrite cores. From a practical point of view, considerable changes in the chemical composition in dendrites occurred in the first three stages of solution treatment. In the case of IR, the greatest changes in chemical composition occurred between the 2nd and 3rd stages of solution treatment.

The relative concentration change (calculated on the basis of EDS measurements) was very high, especially for Re, because dendrites were strongly depleted with Re (Fig. 11).

Characteristic changes in the concentration of elements related to $K$ values were confirmed by investigations of chemical composition along SDAs after each stage of heat treatment (Fig. 12). Some fluctuations of element concentrations along SDAs were observed, but the greatest changes of concentration occurred in the middle of the SDAs (point 3) after the 10th stage of heat treatment (the last stage of aging).

The presented images of the CMSX-4 microstructure after each performed heat treatment scheme are a confirmation of observable effect of the reduced microsegregation.

The calculated values of $K$ (Table 4 ) in as-cast state of the investigated material and after ten steps of the heat treatment scheme confirm the values of $K$ (above and below 1) cited in the literature. However, the quantitative description of elements segregation after so complex heat treatment was never presented before.

The performed analysis of microsegregation seems to be especially important for technological purpose. The proposed heat treatment scheme for single crystal CMSX-4 superalloy is complex and time- and work-consuming, but enables to achieve a microstructure which is beneficial for superalloy potential applications. Additionally, it is noteworthy that according to the results mentioned above, every step of the homogenization was essential because it allows to reduce the microsegregation. The presented results also help realize that diffusion of elements during solution heat treatment proceeds slowly (especially in the case of heavy metals) and requires many hours of heat treatment at high temperature.

\section{Conclusion}

Homogenization during the heat treatment of CMSX-4 superalloy was analyzed using the EDS method. Our investigations reveal that the greatest changes in chemical composition of dendrites occur after the 1st stage of solution treatment, and in the case of IR, between the 2nd and 3rd stage of solution treatment. Therefore, the first three stages of heat treatment play an essential role in the homogenization of CMSX-4 superalloy.
The segregation coefficient $K$ of each investigated element was identified. Our results can provide guidance for obtaining chemical homogeneity during applied heat treatment.

\section{Acknowledgment}

Financial support of Structural Funds in the Operational Programme-Innovative Economy (IE OP) financed from the European Regional Development Fund-Project No POIG.0101. $02-00-015 / 08$ is gratefully acknowledged.

\section{Open Access}

This article is distributed under the terms of the Creative Commons Attribution License which permits any use, distribution, and reproduction in any medium, provided the original author(s) and the source are credited.

\section{References}

1. U. Hemmersmeier and M. Feller-Kniepmeier, Element Distribution in the Macro- and Microstructure of Nickel Base Superalloy CMSX-4, Mater. Sci. Eng., A, 1998, 248, p 87-97

2. R.M. Kearsey, J.C. Beddoes, P. Jones, and P. Au, Compositional Design Considerations for Microsegregation in Single Crystal Superalloy Systems, Intermetallics, 2004, 12, p 903-910

3. R.M. Kearsey, J.C. Beddoes, K.M. Jaansalu, W.T. Thompson, and P. $\mathrm{Au}$, The effects of Re, W and Ru on Microsegregation Behaviour, Superalloys 2004, K.A. Green, Ed., The Minerals, Metals \& Materials Society, Metals Park, 2004, p 801-810

4. N. D'Souza, M. Lekstrom, and H.B. Dong, An Analysis of Measurement of Solute Segregation in Ni-Base Superalloys Using X-Ray Spectroscopy, Mater. Sci. Eng., A, 2008, 490, p 258-265

5. D. Ma and U. Grafe, Microsegregation in Directionally Solidified Dendritic-Cellular Structure of Superalloy CMSX-4, Mater. Sci. Eng., A, 1999, 270, p 339-342

6. M.S.A. Karunaratne, D.C. Cox, P. Carter, and R.C. Reed, Modelling of the Microsegregation in CMSX-4 Superalloy and its Homogenization During Heat Treatment, Superalloy 2000, T.M. Pollock, R.D. Kissinger, R.R. Bowman, K.A. Green, M. McLean, S. Olson, and J.J. Schirra, Ed., The Minerals, Metals and Materials Society, Metals Park, 2000, p 263-272

7. T. Link, A. Epishin, and A. Haibel, Investigation of Microporosity in Single-Crystal Nickel-Base Superalloys by Different Experimental Techniques. Proceedings of EUROMAT 2005, Prague, Czech Republic, 5-8 September 2005. http://www.extremat.org/ib/site/publication/ downloads/Paper\%20Link\%20.pdf. Accessed 23 December 2013

8. N. Warnken, Simulation of Microstructure Formation During Solidification and Solution Heat Treatment of a Novel Single Crystal Superalloy, Shaker Verlag, Aachen, 2007

9. D. Ma, Modellierung des Dendritenwaschstums und der Mikroseigung bei gerichteter Erstarrung, Teil I: Entwicklung eines analytischen Mikromodells, Giessereiforschung, 1998, 1, p 29-34 (in German)

10. A.I. Epshin, I.L. Svetlov, N.V. Petrushin, V. Yu, T. Loshchinin, and T. Link, Segregation in Single-Crystal Nickel-Base Superalloys, Defect Diffus. Forum, 2011, 309-310, p 121-126

11. M. Lamm, "Einfluss der erstarrungsbedingungen auf die mechanischen eigenschaften von einkristallinen superlegierungen bei großen wandstärken, “ [Influence of Solidification Conditions on Mechanical Properties of Single Crystalline Superalloys], Ph.D. thesis, Technischen Fakultät der Universität Erlangen, 2007 (in German)

12. W.S. Walston, J.C. Schaeffer, and W.H. Murphy, A New Type of Microstructural Instability in Superalloys-SRZ, Superalloys 1996, R.D. Kissinger, D.J. Deye, D.L. Anton, A.D. Cetel, M.V. Nathal, T.M. Pollock, and D.A. Woodford, Ed., The Minerals, Metals and Materials Society, Warrendale, 1996, p 9-18

13. J.M. Smialek and G.M. Meier, High Temperature Oxidation, Superalloys II: High Temperature Materials for Aerospace and Industrial Power, C.T. Sims, N.S. Stoloff, and W.C. Hagel, Ed., John Wiley \& Sons, New York, 1987, p 293-326 
14. M.S.A. Karunaratne and R.C. Reed, Interdiffusion of the PlatinumGroup Metals in Nickel at Elevated Temperatures, Acta Mater., 2003, 51, p 2905-2919

15. U. Brückner, A. Epishin, and T. Link, Local X-Ray Diffraction Analysis of the Structure of Dendrites in Single-Crystal Nickel-Base Superalloys, Acta Mater, 1997, 45(12), p 5223-5231

16. R.C. Reed, Introduction. The Superalloys. Fundamentals and Applications, Cambridge University Press, Cambridge, 2006, p 1-28

17. G.E. Fuchs, Solution Heat Treatment Response of a Third Generation Single Crystal Ni-Base Superalloy, Mater. Sci. Eng., A, 2001, 300, p $52-60$
18. M. Gebura and J. Lapin, Microsegregation Induced Inhomogeneity of Coarsening of $\gamma^{\prime}$ Precipitates in a Nickel-Based Single Crystal Superalloy, Defect Diffus. Forum, 2010, 297-301, p 826831

19. T. Grosdidier, A. Hazotte, and A. Simon, Precipitation and Dissolution Processes in $\gamma / \gamma^{\prime}$ Single Crystal Nickel-Based Superalloys, Mater. Sci. Eng., A, 1998, 256, p 183-196

20. P. Wangyao, T. Korath, T. Harnvirojkul, V. Krongtong, and W. Homkajai, The SEM Study of Microstructural Restoration by Re-heat Treatment in Cast Superalloy Turbine Blade, Acta Metall. Slovaca, 2005, 11, p 25-35 